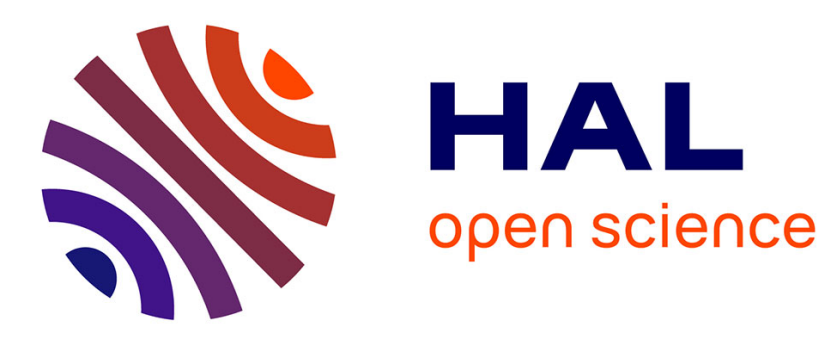

\title{
Morality, Corruption and the State: Insights from Jharkhand, Eastern India
}

Alpa Shah

\section{To cite this version:}

Alpa Shah. Morality, Corruption and the State: Insights from Jharkhand, Eastern India. The Journal of Development Studies, 2009, 45 (03), pp.295-313. 10.1080/00220380802600866 • hal-00518319

\section{HAL Id: hal-00518319 \\ https://hal.science/hal-00518319}

Submitted on 17 Sep 2010

HAL is a multi-disciplinary open access archive for the deposit and dissemination of scientific research documents, whether they are published or not. The documents may come from teaching and research institutions in France or abroad, or from public or private research centers.
L'archive ouverte pluridisciplinaire HAL, est destinée au dépôt et à la diffusion de documents scientifiques de niveau recherche, publiés ou non, émanant des établissements d'enseignement et de recherche français ou étrangers, des laboratoires publics ou privés. 


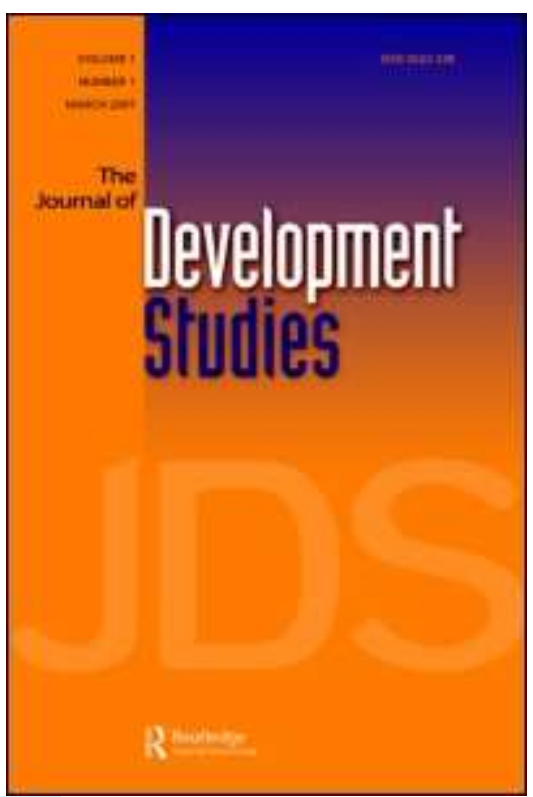

Morality, Corruption and the State: Insights from Jharkhand, Eastern India

\begin{tabular}{|r|l|}
\hline Journal: & Journal of Development Studies \\
\hline Manuscript ID: & FJDS-2007-Apr-0007.R3 \\
\hline Manuscript Type: & Original Manuscripts \\
\hline Keywords: & $\begin{array}{l}\text { Corruption < Government, State Policy, \& Ideologies, State < } \\
\text { Government, State Policy, \& Ideologies, morality, India, } \\
\text { anthropology }\end{array}$ \\
\hline \multicolumn{2}{|l}{} \\
\hline
\end{tabular}

\section{S scholaroNE}

Manuscript Central 


\section{Morality, Corruption and the State:}

\section{Insights from Jharkhand, Eastern India}

The fading hopes of achieving development through strong government in many postcolonial states have meant an increasing focus on 'good governance' by multilateral development institutions. While governance in Africa is interpreted as a return to 'the heart of darkness' (Bayart, 1993), a ‘criminalisation of politics' (Bayart et al., 1999), India is gripped by a pathology of corruption rotting the core of the state (Gill, 1998; Vishvanathan and Sethi, 1998). A central concern of this governance agenda is an idea of a growing crisis: a cancer of corruption whose corrosive spread hinders and obstructs development. Despite the public scandals in the West (see Haller and Shore, 2005) - the proliferation of anti-corruption, accountability and transparency teams committed to controlling and curing corruption centre on the 'Third World'.

Definitions are widely debated but the World Bank $(1992 ; 2007)$ promoted one is popular corruption is the misuse of public property, office or mandatory power for private gain. Corrupt people hinder the developing economy by using public resources for their personal gain. The moral agenda underpinning this argument is that one must work solely for the common good: the spread of corruption is an effect of people satisfying personal interests rather than the collective good of development. The corrupt actor is a rational economic man, usually with dubious moralities, who misuses state resources for private gain. 
This paper argues for a more sophisticated understanding of corrupt practices by showing how they are situated in wider understandings of the state and are underpinned by the interrelations between a moral and political economy. It draws on ethnographic fieldwork carried out since 1999 in Bero Block, Jharkhand, India and focuses on retail corruption ${ }^{1}$ linked to the Block Development Office, the most local level office of the district administration in India and through which programmes of the Ministry of Rural Development were implemented.

Several related points are made. First, defining corruption as underpinned by rational economic action tells one little about localised nuances of morality and legitimacy attached to these practices. Gupta (2005) is correct that narratives surrounding corruption are central to understandings that ordinary people have of the state. However, the reverse is equally true: understandings of the state are crucial to narratives and practices of corruption. The rural elites of Jharkhand, primarily the descendants of higher caste ex-zamindars (landlords) of the area (the main beneficiaries of state development schemes for the poor) understood and, to a certain extent, accepted the idea that the state should act for the common good. However, state determined rules and norms about developmental projects were in practice not seen as beneficial for the common good. They acknowledged that the state could not be separated from the personal agency of the people that make it and shape it; that many state development schemes were inappropriate; and more problematically, that the intended beneficiaries, the poor adivasis of the rural area, were in any case too jangli (wild and savage) to access them.

These rural elites accessed state resources through an informal economy of the state practices that some commentators would consider 'corrupt', the abuse of public resources for private economic gain. History and anthropology have taught us how economic actions of people are defined by a moral economy of rights and expectations, which though may be 
rooted in economic practices, are not determined by financial utility (Scott, 1979; Thompson, 1971). In Jharkhand, ‘corrupt practices' were underpinned by a moral economy and not just indulged in for private gain. They were, as Olivier de Sardan (1999) argues, embedded in wider social relationships and understandings that gave them legitimacy and anchored them in everyday practice. Motivations for engaging in the informal economy of the state included social pressure within a nexus of power relations between individuals, the desire to belong to a particular group of people and become a particular kind of man, and the importance of the relationship between a short and long term cycle of exchange in which morality was governed by a cosmic order. Moreover, a localised discourse on rules and norms was prevalent.

My second point is that communities at the receiving end of development schemes are not homogenous: it is important to address the relationship between different social classes, and their related state access, influenced by distinct yet interdependent values. I thus highlight the multiple moral economies regulating economic action in rural Jharkhand. The majority in this rural region are poorer Munda and Oraon adivasis, tenant descendants of the old village landlords. Unlike the rural elites, they saw the state as inherently and irredeemably beyond the moral pale, wanted little to do with the state, did not accept the idea of the state as acting for the public good, and did not get involved in knowing about state practices. Instead, they promoted an alternative vision of sovereignty, in the form of the adivasi parha.

My third point is that the moral economies within which we should understand 'corrupt' practices are intimately connected to a political economy as seen by Roseberry (1988: 179), whereby social and cultural phenomena are situated in the wider circumstances of sustaining a living and the structures of power that shape and constrain activity. Adivasi perspectives 
were not merely based on cultural or moral imaginings but on a political economy of historical/colonial experiences of state formation and encouragement by village elites colonising the local state and as such interested in blocking those below them in the class hierarchy from interacting in the informal economy of state development schemes on equal terms. My aim in highlighting the political economy of imaginations of the state is to show that adivasis do not have some inherent moral assumptions about the state, but that ideas of morality are historically constituted, managed and reproduced. Transformations in political economy transforms accompany changes in the moral economy. This is evidenced in rural Jharkhand where the power base of the village elites is beginning to be challenged by a new class of educated adivasi youth who are increasingly imagining the idea of the state as acting for the public good and therefore engaging with the state.

\section{The Context}

Jharkhand's doubly marginalised indigenous populations are a focus for developmental efforts. Marginalised because they live in a state housing one of India's poorest populations where, in $1997,63 \%$ of its 26.9 million people were thought to live 'below the poverty line', with $78 \%$ in rural areas, and where only $40 \%$ of villages have road access and $15 \%$ have electricity. Doubly marginalised because many are thought to be so lowly as to be placed outside the caste system. These are the people officially designated Scheduled Tribe status, more popularly known as adivasis, and in colonial times called tribals. The majority of development resources come through the official state machinery via the Block offices.

The paper begins with an account of a 1999 conflict in the Bero Block Development Office but also draws on ethnographic research exploring the wider rural area from a base in a 
village called Tapu. With a population of about 550 people, Tapu represents the historical deep divisions of the area. On the one hand, approximately $20 \%$ of the population are descendants of the old landlords, the rural elites. Although the rural elites include a few adivasi descendants of land revenue collecting families, the majority are all higher castes, collectively known as sadans. On the other hand, there are descendants of the old tenants, adivasis (mainly Mundas and Oraons and constituting 60\% of the region's population), and some dalits and other lower castes.

At first glance, the differences between the sadan elites and the adivasis may not be very apparent. The sadans also lived in mud houses and had neither electricity nor sanitary facilities. They also fetched water from wells or water pumps, collected firewood from the forest, farmed their fields and sometimes even partook in manual labour. These similarities marked an 'aesthetics of poverty', that is the power of the seductive visual imagery of poverty, through which it is easier for development schemes to legitimise why these rural elites are the main beneficiaries of development resources in the name of the poor - most of the rural elites are registered on the government 'Below Poverty Line' list and on the 'Red Card' lists of the Public Distribution System for the poorest, whilst most adivasis are not.

However, a deeper analysis that moves beyond an 'aesthetics of poverty' - and that addresses poverty not simply in terms of material resources but also as a form of systematic sociopolitical exclusion from the development process - may draw attention to some marked differences. For instance, the sadans usually had larger plots of irrigated land and more cattle than the adivasis. The sadans had family bank accounts. Although literacy rates were low in the village, their children attended at least primary school. But perhaps the most important difference for this article is that whereas the sadans maintained their livelihoods through 
direct and/or indirect benefits from the developmental machinery infiltrating the rural areas, most often in the form of the state, the adivasis sought to keep outside authorities such as the state away. $^{2}$

The hostile antagonism, mutual disparagement and contrasting values of the sadans and the adivasis explored here are partly explained by the socio-economic history of this Jharkhand region. One result of the eighteenth century colonial land settlement policies, the higher caste landlords of the area displaced lower castes and tribes from other areas and brought them as servants to villages they controlled. In return for their servitude, the landlords gave them a small amount of land to cultivate. In 1932 while the average size of a landlord landholding in Tapu was 33.2 hectares, that of an adivasi was about 8.3 hectares. By 1992, however, the land reform changes of the fifties (such as the Bihar Land Reforms Amendment Act which placed a ceiling on land ownership), meant that the disparity had somewhat lessened and all the adivasis now owned some land. Moreover, the landlord descendants had an average landholding of 2.7 hectares and the adivasis, 1.8 hectares. As a result of these changes, coupled with the now broken social contract of adivasi servitude to the landlord descendants, the latter sought alternative routes to maintain their local dominance. From land, their attention turned to a control over state resources, whether directly (from government jobs) or indirectly (through, for instance, development contracts). The sadans had different aspirations from the adivasis who they looked down on and often called by the derogatory term 'jangli'. In contrast to those above them in the class hierarchy, the poorer majority were in fact often proud to be of the Jungle Raj (the Forest Kingdom) and of the values this entailed. They generally sought to keep the state away, lived off arable and livestock agriculture, fruits and leaves from the trees and manual labour. These changing material 


\section{Incomplete Building}

Bero 1998. A cheque of Rs2 lakh (£3100) arrived for the construction of a training centre for the Development of Women and Children in Rural Areas (DWCRA) - one of several schemes implement by the Block Development Office (or Block Office). ${ }^{3}$ Launched in 1982, and partially funded by UNICEF till 1996, DWCRA was a Ministry of Rural Development response to a male bias in poverty alleviation programmes. In line with the emerging popularity of micro-credit/micro-enterprise schemes, DWCRA aimed at improving poor women's economic condition by promoting their collective participation in self-help income generating activities.

The Ministry's role in this 'empowerment' of women was, generally, low resource. The Ladies Extension Officer, Kamini Srivastava, ${ }^{4}$ the only female officer in the Block Office, was to introduce DWCRA's 'participatory principles' to poor rural women. She worked under the Office head, the Block Development Officer, Makhan Pandey, and, like most Jharkhand officers, was of Bihari high caste origin. The Ministry was to train beneficiaries, provide a revolving fund of Rs 25000 (£385) for raw materials and, as a one-off payment to certain groups, money to build training centres.

In the Bero DWCRA files, largely eaten by white ants, fourteen groups existed and the records were unchanged over time. In the State's capital Ranchi, the District DWCRA 
supervisor declared the 14 Bero groups successful: four new ones would be formed in 1999 . Meeting paper targets was essential to receiving the next monetary instalment from the Ministry. In fact, Bero Block officers acknowledged that of the 14 groups only two really existed - in the villages of Pokal Tikra and Karanj Toli. Pokal Tikra, the model group, was chosen as the site for the training centre.

The output produced determined 'success' and Pokal Tikra was considered successful because they produced hand-woven carpets. However, the officers were careful not to mention to visitors that the carpets were woven in a 'factory' run as a Non-Governmental Organisation (NGO) by a woman named Sumani Devi. Whilst Sumani was a Maheto caste descendant of the ex-zamindars of Pokal Tikra, the DWCRA beneficiaries were all adivasi women who were descendants of the ex-tenants of the landlords. They walked two kilometres from the adivasi dominated hamlet, Sember, to work on Sumani's handlooms in Pokal Tikra's main hamlet. Unsurprisingly, in the fiasco that evolved over the building, Sumani was a central actor.

The construction of any Block Office building attracts attention amongst the officers because commissions taken as 'percentages', or 'pcs' off the money for the scheme. The money arrives from the District Office in the name of the Block Development Officer. The contractor receives the money in instalments for which a series of documents have to be signed by various officers. Percentages are taken while signing these documents. In all construction programmes there are two sets of sanctions: in the technical and the administrative wings. For example, in the technical wing, the Junior Engineer can take 10\%, Assistant Engineer 3\%, Executive Engineer 1.5\%. The administrative wing includes the Block Development Officer who can take 5\%, the supervisor 3\%, the head clerk 3\%, the 
cashier $2 \%$ and the assistant clerk $1.5 \% .^{5}$ If the costs can lower, the cuts are higher.

Altogether, approximately $30 \%$ of the scheme money goes to the Block staff. ${ }^{6}$ These 'systems of mediation' are significant in making the otherwise resource-poor DWCRA a low priority for the officers. However, when Pokal Tikra was chosen as a site for the Rs2 lakh DWCRA centre, DWCRA became the focus of Block Office attention.

But these construction schemes were also the centre of attention for the rural elites. As part of the participatory development mandate, through which villagers chose schemes, public petitions for particular schemes were brought in by the rural elites to the Block Office. Only some of the proposed schemes would be selected and schemes promoted by influential elites, especially those backed by a Member of Legislative Assembly (MLA) or a Member of Parliament (MP), were preferred. ${ }^{7}$ Once a project was selected, a village contractor was to be chosen through a public meeting. Often, these meetings did not take place, as influential elites would fix outcomes. When they did take place, meetings were dominated by rural elites competing with each other.

The choosing of a village contractor was a highly fraught affair as potential contractors could siphon off up to $10 \%$ of the total sum of the project by poorer quality materials and shallower foundations than proposed, or by accounting for twice the number of labourers who worked.

In the meeting to choose the Pokal Tikra DWCRA training centre contractor, although Sumani's proposed candidate stood in election, another man was chosen. Furious, Sumani accused the head of the Block Office, Pandey, of fixing the results. She claimed that Pandey had backed a worker of the Congress Party MLA who, in return, would secure his next transfer of post. Sumani also claimed that the chosen contractor would enable the smooth 
operation of the systems of percentages, and would negotiate a particularly good bribe for Pandey for commissioning the project. Moreover, she declared that the chosen contractor wanted on his land to colonise as a drinking club for men.

Pandey denied these allegations: the decision had been democratic. He urged Sumani to stop interfering in Pokal Tikra affairs: she was a woman and an outsider who had returned to her natal village after a failed marriage. Moreover, she was not poor, and should have no role in DWCRA whose beneficiaries were supposed to be 'Below Poverty Line'. Finally, Pandey argued that the 'real' reason Sumani was angry was because she wanted the building on her land to capture as a house extension.

In response, Sumani mobilised Sember residents to strike for fifteen days from the agricultural labour that Pokal Tikra ex-zamindars depended on. She caused substantial problems and threatened further trouble. When the foundations were dug, Sumani asked Sember villagers to fill them with stones. The confrontation worsened. One night, a group of armed men, claiming they were underground Maoist guerrillas, beat up the contractor and two family members. The rumour spread that Sumani was behind these developments. Sumani also took 30 Sember women to the Deputy Development Commissioner and District Commissioner in Ranchi to complain against Pandey commissioning the building to an inappropriate contractor.

Deterred by these developments, Pandey (in whose hands the ultimate authority of all Block decisions remained), wanted to cancel the project all together. His strategy was to feign ignorance about the 'real' conditions of the 'model' DWCRA group. He staged an official 
visit by Srivastava so that the Block Office would 'discover' the group's failure to function under the guidelines.

Srivastava's visit to Pokal Tikra was unannounced. I accompanied her. Srivastava asked for the DWCRA group leader as we entered a room with two handlooms worked by Oraon women. The women looked scared, did not reply and continued working without taking their eyes off the looms. Eventually one of them called for Sumani. Srivastava shouted, 'Sumani is nothing to do with DWCRA.' Sumani welcomed us with Moti Devi, the alleged leader of the carpet-weaving group. The next hour saw an explosion of accusations between Srivastava and Sumani.

Srivastava ignored Sumani and asked Moti for the DWCRA files. The files were blank and Srivastava criticised the group for not maintaining them. Moti was shaking, nervous and nodded at everything Srivastava said. Sumani, however, fought back. She asked how Moti was supposed to know about maintaining files when Srivastava had never shown her. She attacked Srivastava for acting like all state workers, frightening the women, not caring about them, never coming to see them, and not explaining how DWCRA should work. She pointed out that DWCRA was not about file maintenance but income generation. The heated argument escalated. Srivastava told Sumani that she had no right to interfere. Revealing her awareness that the DWCRA group had never really existed, she argued that Sumani was in fact exploiting DWCRA women as factory labourers. Sumani argued that at least her 'factory' provided a job for the women and wasn't just a programme only on paper.

When we finally left Srivastava was fuming. She had, however, accomplished the task of 'officially' uncovering that the DWCRA group was not functioning because of Sumani's 
interference. The Pokal Tikra group could be closed and the matter of the building dropped. When I returned for further fieldwork in 2000, the building, like many others, remained an abandoned incomplete construction.

\section{Corrupt activities are not just explained by financial utility}

The negotiations, percentages, bribes and gifts that characterise the informal economy of the developmental state in Jharkhand would have stopped, in this case, when the DWCRA building was abandoned. Nevertheless its contests give a flavour of the political landscape of the informal economy of block development schemes and its analyses might enable a deeper understanding of the processes shaping practices termed 'corrupt'. In what follows, I begin with people like Sumani and the competing contractor to show the multiple factors affecting their engagement in the informal economy of the state. In much of the literature these contractors are called 'mediators', 'intermediaries', or 'brokers', blurring the boundary between the state and society (Gupta, 1995; Gupta, 2005; Neocleous, 1996), sometimes perpetuating patron-client relations (Bailey, 1969), at other times more positive forces of civil society, creating order in the fragmented politics of the post-colonial state (Bierschenk et al., 2002; Lewis and Mosse, 2006). In Jharkhand, they all emerge from the rural elites, usually the descendants of higher caste ex-zamindar, but sometimes Scheduled Tribe ex-revenue collecting families. Unlike Sumani, most mediators in the Bero area were men.

In the World Bank perspective these contractors are rational economic individuals maximizing personal gain. Since the abolition of zamindari in the 1950s, state benefits were a central means through which many zamindar descendants attempted to maintain their wealth. Block Office contracts were important as their implementation offered the opportunity to 
siphon off funds. However, whilst the objective may be obtaining material benefits from the state, being a contractor was not solely about financial gain.

\begin{abstract}
Amongst potential contractors, for instance, securing contracts was also about aspiring to particular ideas of masculinity - a modern man of the town who hob-nobbed in the streets, restaurants and shops of Bero and became part of a peer group of young men acquainted with state activities and officials, built personalised relations with those 'in the know', and developed skills of being in the right place at the right time. Circulating in these elite networks in Bero was exciting in comparison to the more mundane village environment. It was a challenge to become accepted to wine and dine amongst these networks. ${ }^{8}$
\end{abstract}

\begin{abstract}
Becoming accepted was one thing but acquiring status was another. In the village, status came with birth, but in Bero young men had to secure their credibility amongst the 'worldly actors' of predominantly ex-zamindars. Tension and conflict over state resources was rife. The men were linked to branches of a political party, whose most prominent personnel campaigned for the MLA seat every five years. Particular candidates were supported in the hope that victory would influence the distribution of development contracts in favour of allies.
\end{abstract}

Becoming accepted, acquiring status and securing a contract, required skill and tactics to perform and 'do' 'politics'. One had to be shrewd, intelligent but also willing to engage in 'dirty' activities (c.f. Goldman, 2001; Ruud, 2001). 'Dirty' not just because of the tactful alliance building involved, but also because of the secrecy, caution and the potential to stab allies in the back if they became a threat. 'Doing politics' was dangerous. While many young men of zamindar descent tested their ability to do politics, only some sustained involvement 
for more than a couple of years. 'Doing politics' was often a transitory and transient activity - a life-cycle experience, after which one settled down to a more 'peaceful' existence.

In summary then, the financial utility of pocketing illegal money from Block development schemes were not the only attractions for Bero elites to interact in the activities many would call corrupt. Far from being rational economic maximising concerns, engaging in 'corrupt' practices was also about the non-material interests of becoming accepted amongst a particular group of people; acquiring status within that group; a life-cycle experience of the challenge and fun of doing politics.

\section{The moral economy of 'corrupt' practices}

The multiple reasons why rural elites engage in 'corrupt' practices were accompanied by a complex moral economy. A number of points of interest emerge. Firstly, illegality does not equate to immorality. Money made from contractor cuts was locally called second order work, resulting in second order money (distinct from first number work and money from farming or hard manual labour), because it was thought to involve illegal activity. Second order work, however, was not condemned by the village elites for its illegality (c.f. Harris, 1996). In fact a localised moral discourse about the state legitimised second order work.

Thus, secondly: 'corrupt practices' were legitimised because there was generally a lack of commitment to the state as it manifested itself in rural Jharkhand. Underlying the international discourse on corruption is the idea that for progressive economic development, people in modern society should submit to the state the ability to define and police the principles of morality, or good behaviour, for the collective good through impersonal rules - 
such as the rule of law. Thus as Robertson reminds us, 'what in modern times we have been calling corruption is a byproduct of the formal rules that seek to separate persons from the offices they hold' (2006:8). There is, as Hart points out, a huge effort involved in separating the impersonal state from personal agency. When people step across this division, the word often used is 'corruption' (Hart, 2005:29), and is one reason why some explain the origins of corruption as the extreme personalisation of power relationships (Bayart, 1993). Corruption violates the fundamental idea of the state as an impartial servant of the people, as the nonpersonal guarantor of a certain impersonal social order. This idea is a crucial one because the legitimacy of modern states, to a large extent, rests on this claim (Mooij, 1992). Yet, as anthropology has recently shown us, the separation of the impersonal state from personal society is highly problematic - there is a complex relationship between personal agency and impersonal institutions - personality/personal agency is intrinsic to bureaucracy (Brass, 1997; Fuller and Harriss, 2001; Gupta, 1995; Gupta, 2005). In Jharkhand, the state was thought to be incapable of fulfilling the promises of a servant of the people, the guarantor of a certain social order, and a power above partial interests because it was recognised to be run by people with personal agendas and whose vision of the common good was removed from that of ordinary rural people. Moreover, second order work was legitimised because most development schemes were thought to be inappropriate for the rural areas as they were designed by New Delhi officials. For instance, both Sumani and Srivastava agreed that rather than a fancy income generating project, rural women needed a factory for their 'development'. Rural elites, in fact were often prejudiced towards the poorest in the rural areas. Development schemes were considered wasted on jangli adivasis who were too uncivilised to care for or know what to do with them. Like Sumani, many rural elites actually legitimised their activities by arguing that they were expropriating state resources for more 
useful purposes, even calling themselves 'sevaks' or 'social workers' to outsiders (c.f. Mayer, 1981).

Thirdly, engaging in 'corrupt practices' entailed highly morally charged discussions around who got contractorship, why and the way in which the contractor's cut was spent. While exzamindars saw contractorship as their hereditary right, those wanting to join these elite networks took the more democratic approach that all educated young men should have the opportunity. As Sumani's case shows, the moral discourse on contractorship can be gendered. When a woman tried to gain contractorship she was condemned for intervening in the world of men. Moreover, as the number of potential village contractors rose, there was an increasing trend towards rival contractors condemning each other for using do number paisa for selfish ends. As a result, competing village elites now pressurised contractors to divert their cut to other common village causes, especially as religious donations (c.f. Mosse, 2001). In Tapu, a moral discourse around money siphoned off from construction contracts was emerging that in many ways appeared to mirror the relationship between short-term and longterm exchange described by Parry and Bloch (1989). Contractors had to convert, and hence purify, their second order money from individualistic short term exchanges of contractor cuts into first number sums, in this case of a long term transactional or cosmic order of religious capital by contributing to the building of a Hanuman temple.

Fourth extra-legal activities were differentiated and all were not equally condemned. The giving and taking of chai-pani (literally meaning tea-water) ${ }^{9}$ the pagdi (the bribe); and the $p c$ or percentage, matching Parry's (2000) useful distinction between the gift, bribe and commission, were all differently morally evaluated. Gift giving was the least reprehensible not only because it was part of a broader social system of maintaining relations between 
people, but also because it was considered willingly engaged in. In contrast, the bribe was rarely voluntary on the part of the donor, and thus its giving was sometimes with resentment. Furthermore, the bribe's negotiability engendered feelings of unethical practice, especially if one had to give more than others. The commissions, the third form of payment, were a fixed percentage of the value of a scheme given by contractors to different officers, expected and contracted in a manner that was so 'matter-of-fact' that they were rarely considered morally wrong. Indeed, it was mainly deviations, not the percentages themselves, which were deemed morally wrong. For example, if an officer tried to take more than his allocated percentage, she would most likely be regarded as greedy. Yet if an officer did not take their allocated percentage s/he may be regarded with respect, not because they acted legally, but because those who were not greedy were praised. In a similar vein, if a contractor tried to get away without paying the commission, s/he would be considered immoral. This would also hold for those who escaped payment due to caste or kinship relations with the officers. Thus morality in the discourse of corruption was often judged in the context of values such as caste, negotiability, gift giving, hierarchy and greediness.

Fifth, the alleged immorality of 'corrupt' activities was sometimes a performance, a tool with which village elites played out the competition between them. In fact we need to segregate the practices of what is called corruption (but which often amounts to legitimate economic activity) from corruption as a discourse used to delegitimise others/political opponents. For instance, Sumani claimed that Pandey had backed the chosen contractor because he would submit to the system of percentages and bribes. However, she also told me that if her candidate had received the contractorship she would also have given the percentages. The officials were also engaged in a certain performance of morality around DWCRA. It was clear that everyone had known for years that the DWCRA groups were paper targets, and that 
even in Pokal Tikra, the group were really factory workers. Yet, only when things had not gone according to Pandey's plan, was Srivastava sent to 'discover' that Sumani had turned the DWCRA women into factory labourers, in order to cease the construction.

Exploring some of the wider context of the DWCRA building shows that people's engagement in practices some would call 'corrupt' is not just for financial utility but also for a range of non material reasons and moreover, that these practices were governed by ethical norms and debates. However, the moral economy of rural Jharkhand is multivarious and a different class of rural peasants, represented by the women who worked in Sumani's factory, the adivasi labourers, have a different view of the state. And it is to this moral economy that I now turn.

\section{Multiple moral economies: adivasis}

The tenant descendants of the zamindars, the majority of who were adivasis, saw the state as alien, dangerous and best kept away from. I describe this moral economy in further detail elsewhere (Shah, 2007) and here outline the main arguments. Exemplary of the way in which those in the margins of stately power are often complicit in reifying the state (Taussig, 1992:132), adivasis constructed the state as an abstraction, as inherently and irredeemably beyond the moral pale, and not in their common good. In Tapu, the state with its officers and development projects took on an almost ominous Kafkaesqe quality for the Mundas, encompassed in the term sarkar.

Whenever a state jeep arrived in Tapu, for example, whereas the landlord descendants rushed to greet the visitors, the Mundas would steer well away. Somra Munda once said, 'In the 
olden days when sarkari (state) people arrived, women would rush into their houses, sweep children in and close doors, and men would even hide in the forest.' This fear of the state has also been noticed in the neighbouring state of Chhattisgarh, but also historically amongst adivasis of Western India. ${ }^{10}$

There were several reasons for adivasis' desire to distance themselves from the state. Firstly, their attitudes are embedded in the history of colonial state-formation which proved very exclusive and exploitative for poor adivasis. Colonial processes of land settlement and elite formation resulted in outside state officers and moneylenders (the outsiders were called dikus) working with and producing landed elites, zamindars, alienating adivasis from their land, taking over their forests, and rising indebtedness (Guha, 1999 (1983); Singh, 1966). The foreign state officers carried on into the post-independence period in the form of Hindu high caste Biharis with their exploitative and oppressive policies.

As late as the nineteen eighties, the police were the most significant experience of the state for the Tapu Mundas. In the late seventies and in the late eighties, two murder cases resulted in the arrest of several Mundas in Tapu who were tortured by the police - their feet were whipped and their families were crippled by the incurred legal costs. The other significant experience of the state was excise officers, who local people associated with the police, and who came to the village to beat those selling rice beer and mahua wine. In Tapu alcohol was important for every Munda festival and family ritual occasion and each Munda household brewed rice beer and mahua wine for domestic consumption. While this domestic consumption was not prohibited in Jharkhand, the sale of alcohol was. Inevitably, everybody sold excess created from domestic consumption (and especially at the time of festivals) to needy neighbours. Thus, crackdowns on the sale of alcohol by excise officers drove the fear 
of the state into every single Munda household. This fear was further enhanced when one person was jailed for several years. The result, unsurprisingly, was that the state was seen by adivasis as part of an 'outside and foreign' world: dangerous, unpredictable and best kept away from. Indeed, a common term used by adivasis to describe sarkar was 'soccion' (exploitation).

In recent years the state was seen as becoming increasingly sophisticated in its ability to exploit adivasis and this was evident in its most recent camouflage as block officers who were seen to disguise their destructive capacity in a language of 'acting in the interest of the poor' (see Shah, 2007). As such, adivasis rarely showed interest in ration cards which would enable access to government subsidised provisions and in being on 'Below Poverty Line' (BPL) lists for state development schemes. Where adivasis accepted state resources, closer investigation demonstrated that it was often under the influence of village elites. In fact, and most strikingly, in these circumstances they often believed that the resources came not from the state but from the elites themselves. For instance, the women in Sumani's factory were unaware that they were the beneficiaries of a state-run DWCRA programme. Instead, they saw themselves as labourers in Sumani's factory. In other cases, albeit always through the encouragement and mediation of the rural elites, adivasis sometimes accessed state resources for what they saw as compensation for damage created by the state.

As such many adivasis idealised a former time when, in the absence of sarkar, adivasis society had been stronger - a time of the parha, an adivasi sacral-polity, a sovereign structure, which consisted of groups of 12 to 21 villages, ruled by a parha raja at the intervillage level, and at a village level, by local functionaries called pahans and paenbharras. This sacral polity was responsible for resolving all disputes, embodied a non-self-interested, 
non-divisive and moral politics endorsed by the spirits (Shah 2007), and was fundamentally underpinned by the values of egalitarianism, consensus in decision making, reciprocity and mutual aid. In contrast to sarkar as a destructive source, the parha was imagined as an alternative, authentic, adivasi political vision. In recent years this vision of the parha has been revitalised by local Members of Legislative Assembly who, as I argue elsewhere (Shah 2007), endeavour to win the adivasi vote by promising to keep the state away and instead resurrect the parha. The parha was seen as the essence that united and protected adivasis an essence that had, in recent years, been weakened by sarkar. For instance, a common example of the weakening of the parha was the rise of the modern courts that were expensive, controlled by cheating outsiders who lacked spiritual legitimacy and undermined the consensus generating dispute solving function of the parha. Many Mundas attributed the waning strength of the parha sacral polity in recent years to the waxing power of sarkar.

Some of the younger generation, to whom I will return, educated and aspiring to join the village elites, had more contradictory understandings of sarkar and often looked down on the ideas of their relatives and parents, attributing them to 'illiteracy'. Their kin, however, explained the youth's disenchanted attitudes as further evidence of sarkar's increasing power to mislead the new generations. In fact, many explained that by grabbing those who engaged with it, sarkar brought an amoral, self-interested politics into village life, further dividing it. Given a choice, adivasis ex-tenant descendents preferred to have nothing to do with the state and its officials. Fearful of the state, they preferred to leave contact with the state to the zamindar descendants. They rarely acquired the kinds of detailed knowledge of state operation that some members of the rural elites accumulated, and furthermore, cared little this was the case. There was good reason to see why the state is beyond the moral pale for the 
adivasis. A historically/and colonially based political economy has marginalised adivasis and explains adivasis morality vis-à-vis the state.

\section{Ideas of morality as underpinned by a political economy}

Adivasi perceptions of the state were underpinned by the above historical and material reasons but also a contemporary political economy in which village elites and local state officials acted as mediators reproducing and reinforcing adivasi imaginations of the state. ${ }^{11}$ As Nuijten (2003) argues, brokers play a role in the fantasies of state power (c.f. Bailey, 1969: 169; Collier, 1976). Block officers and local elites needed each other to capture state resources and both needed to limit the pool of contractors: village elites wanted to secure outcomes and block officers did not want to disappoint contending contractors or their political patrons who could hold some leverage over officers and also wanted to enhance the conditions for the trust-building necessary to ensure that the bribe-giver would pay. The number of contractors are most easily limited if people would not consider becoming contractors in the first place. This was enabled by a reproduction of the discourse that the state is so alien and malign that the adivasis would not want anything to do with it. It is in the interest of the village elites to performatively reinforce (even exaggerate) the idea that the state is totally corrupt - the discourse of corruption is itself an important weapon for the rural elites.

Adivasis trying to access land revenue documents, caste certificates, or signatures from officers were given an endless run around until it was eventually 'proven' to them that they needed their village patron to get the job done. Performative dimensions of village elites reinforcing adivasi understandings of the state are described elsewhere (Shah, 2007), but let's 
While some of the zamindar descendants would quite willingly joke to me about the stupidity of adivasi beliefs about the state, in front of them they would perpetuate the notion of an exploitative monolith it was better to stay away from. They realised that the discourse of state exploitation was an important narrative to reinforce and even exaggerate. Capturing the local economy of the Block Office was more easily enabled by creating a network of personalistic ties between state officers and village elites from which others were excluded. This 'blocking' was enabled by taking every opportunity to stress the cultural differences between honest, innocent, ignorant, illiterate, insiders (the ex-tenants) and corrupt, exploitative outsiders (the state and its agents). Keeping others misinformed about the roles of the state was key to controlling state resources. Control of state resources by the officers and village elites was based thus on control of both the idea of the state as functioning for the public good as well as the localised practices of the state. Part of the reason that adivasis today continue to hold the moral view of the state as irredeemably foreign and to be kept away from is the result of a localised political economy in which it has been in the interest of other villagers to propagate and reinforce such a view. 


\section{Transforming political economy: transforming moral economy?}

These different localised understandings of the state, as well as their reproduction, hold important implications for development policy. In recent years, participation and decentralisation have been major buzzwords targeted to make development more democratic, more likely to reach the poorest and to decrease corruption. However, because these tend to treat the localised community and its moral economy as homogenous, there can be little assurance that people will really be better served. The community and moral economy is differentiated and dominant local interests effect changes over time in their own interest, shaping the way in which development programmes are implemented locally (c.f. Corbridge and Kumar, 2002). In this context, it is more likely that changes to local class structures, as a result of a shift in the localised political economy, will effect changes in adivasi morality visà-vis the state, rather than initiatives that encourage decentralisation and/or participation per se.

Indeed, in recent years there is evidence that things are slowly changing as greater numbers of adivasis have sought to enjoy middle class lifestyles and village elite status. The seeds of these changes were evident in the pre-independence period when Christianisation of adivasis increased their access to education and led to the emergence of a small tribal middle class that was in fact responsible for the fight for the separate state of Jharkhand (c.f Corbridge, 2000; Das, 1992). More recently, even in villages like Tapu that have remained on the margins of the state, parents were beginning to send their children to school, in part because of increased opportunity to do so created by government reservations for people of Scheduled Tribe and Scheduled Caste descent (c.f. Corbridge, 2000). Indeed, whilst in much of the Bero area, this expansion of the developmental state has had, as might have been expected, a 
disproportionately beneficial effect for the rural elites, it has offered some adivasis, previously confined to village and kinship based networks, the opportunity to move out into the previously 'foreign' world of the state and the middle class. In so doing, this emerging middle class has begun to view society in new ways and to understand both the idea and the practices of the state. ${ }^{12}$ Whilst the majority of adivasis in Tapu retain the understandings I have discussed, an emerging transformation is evident among no more than a handful of younger Mundas, and is resonated in the politics of state contractorship in the village.

The first Block Development Office scheme was implemented in the village in 1996 and has been followed by one every year thereafter. While there were always tactical battles among potential contractors, until 2001 all the elected contractors were sadan men. In the last few years, however, these elections have precipitated increasingly fraught conflict between a few young educated Munda men on the one hand and the zamindar descendants on the other. The young Mundas, unlike their parents, have escaped the essentialised view of the state as something to be feared. This is a result of the process of their school and college education, which has given them opportunities to understand the state and its agents in different ways.

Ironically, a brief trip to the Bero area between January and March 2007 revealed how it is now in the interest of Tapu ex-zamindars to leave the 'dirty' politics around state development schemes to the new generation of Munda youth. By 2007 many zamindar descendants found other means to diversify their livelihoods - Neel had received contractorship of the village Public Distribution System shop. Moreover, the Bero area saw the expansion of the underground left wing Marxist-Leninist-Maoist inspired guerrilla movement, commonly called the Naxalites, who are expanding, as I have argued elsewhere (Shah, 2006), through offering better protection to village elites involved in the informal 
economy of state resources, thus blurring the boundary between the 'terrorist' and the state. In the context of the increase of fear, suspicion and a more violent atmosphere accompanying the greater influence of the Naxalites, some village elites who want to avoid the Naxalites, are now feeling that perhaps it might be better to leave state development contractorships to the new generation of Munda youth.

But as an emergent adivasi class enters the spheres of the state, many more are left feeling that this is further evidence of the state's malign strength. Parents, for example, who used to strongly disapprove of their son's involvement in state activities now see the dangers of the state in many more forms - including the Naxalites. They, like many adivasis more generally, retain the belief that the state corrupts individuals and weakens adivasi society. And one result is that their belief in the alternative sovereign structure, the parha, strengthens.

\section{Concluding remarks}

In the last two decades, we have seen the rise of what has been termed a 'culturalist critique' (Fuller and Harris, 2001) of the Indian State which argues that the notion of the postcolonial state in India is an alien ideology that some of its citizens will necessarily culturally misunderstand. An influential line of thought sees the 'failure' of the postcolonial state as India's 'natural' rejection of imposed social change and, furthermore, as evidence of a broader pattern inherent in India's experiments with modernism. The most extreme proponents of this argument are Nandy (1998) and Madan (1997) who believe that a Westernised elite imposed alien secular Western institutions over ordinary people who considered religion as the determining principles by which social conduct should be 
governed. Variants of this argument, albeit less historically and culturally reductionist, are implied in the work of Kaviraj $(1984 ; 1991 ; 1997)$, but also Chatterjee (2004), who following Gramsci argue that the form of the western liberal postcolonial state exported for India by its modernising bourgeoisie was unintelligible for its subaltern populations at the time of Independence. Social transformation was not driven from within society but was a function of domination attempted through a state-bureaucratic agency and a 'passive revolution' that substituted planning for political reform (Kaviraj 1984: 225-227; 1991: 80).

In this vein of argument, Chatterjee (2004) has pointed out that many popular terms used to describe everyday localised practices of governance, such as 'civil society', are really categories of a bourgeois political order which are extremely limited in much of the nonWestern world. In India, it does not make sense to insist on localised practices to respect the rule of law, equality of law, protection of private property, freedom of contract, because most people are not bourgeois and just do not negotiate claims to the modern state in this way. He suggests instead, a term, 'political society', to describe the way in which localised subjects operate on a set of norms which are often quite contrary to what the larger principles of governance would dictate.

This article has shown the shades and textures of this political society in relation to the debates around corruption, morality and the state, from the localised perspective of the actors concerned. Understanding this 'political society' is important because we are faced with an increasingly powerful international development discourse condemning corruption in the developing world. The need to understand people's moral reasoning about actions which some would consider corrupt in their own terms is pressing if we are to get away from the idea of corruption as some how pathological. In the Jharkhand case, a number of interrelated 
points emerge: First, monetary aspects of 'corrupt' activities may be eclipsed by a whole range of other motivations, governed by a set of moralities, for engaging in those activities. As noted long ago by Thompson (1971) and Scott (1979), economic action is governed by a pattern of moral rights or expectations. Second, moral reasoning about corruption might itself be a tool through which potential opponents are fought off. Third, the institutional dualism at the heart of moralistic good governance discourses on corruption, forcing people to separate personal agency from the state, might well be less honest than an open acknowledgement of their interdependence (c.f. Hart, 2005). While it might be accepted that the idea of the state should be impersonal in order to serve the greater common good, it is also accepted that the state after all consists of real people doing things to and with each other and who are often designing policies and development schemes without having any idea about their relevance for the people they should allegedly serve. Fourth, the moral set up of everyday life does not necessarily agree with official or dominant rules and moralities. Fifth, what is legal is not necessarily that which is the most legitimate. Often, the violations of state norms may be determined by their perceived inadequacy to live up to the idea of the state as a public body working on behalf of the common good.

While understanding 'political society' is important, the Jharkhand case crucially warns against a promotion of culturalist arguments about corruption - for example, different cultures perceive economic practices in different ways. Instead, we need to understand the complex interrelationships between how people reason about their 'corrupt' practices in the wider socio-economic context of understandings of the state, and the multivarious moral and political economy determining social action. 'Political society' in rural Jharkhand is differentiated and has neither a uniform nor a hegemonic moral economy. A fine-grained analysis unravels different moral economies and a majority of the rural poor, primarily 
adivasis, who want nothing to do with the state, do not accept the idea of the state as acting for the public good, and do not get involved in knowing about the practices of the state, and resurrect an alternative sovereignty, a parha sacral-polity. These are not merely cultural imaginings of the state but result from a political economy of historical experience of the state as well as ideas encouraged by the village elites in whose interests it is to promote the idea of the state as alien, dangerous and so beyond the moral pale that adivasis ought not to engage with it. Perpetuating such views of the state, the rural elites are better able to block the rural poor from interacting in the public sphere and the moral economy of state development schemes on the same terms as they interact. Ideas of morality in this instance are also historically constituted, managed and reproduced.

The Jharkhand analysis leaves open two possible future trajectories for adivasi-state relations which may of course run parallel to each other. The first is a continued rejection of the state and a sustained adivasi movement to resurrect the sacral polity of the parha. The second is a transforming political economy: as is evidenced in rural Jharkhand with the emergence of a new class of adivasi youth aspiring to join the rural elites, which in turn impacts a transforming moral economy. 


\section{References}

Bailey, F.G. (1969) Stratagems and Spoils: a social anthropology of politics. (Oxford: Basil Blackwell).

Bayart, J.-F., Ellis, S., and Hibou, B. (1999) Criminalisation of the State in Africa. (Oxford: James Currey).

Bayart, J.F. (1993) The State in Africa: politics of the belly. (London: Longman).

Bierschenk, T., Chaveau, J.P., and de Sardan, O. (2002) Local development brokers in Africa: the rise of a new social category. : Department of Anthropology and African Studies, Johannes Gutenberg Universitat, Mainz, Germany.).

Brass, P. (1997) Theft of an Idol: Text and Context in Representation and Collective Violence. (Princeton: Princeton University Press).

Chatterjee, P. (2004) The Politics of the Governed: reflections on popular politics in most of the world. (New York: Columbia University Press).

Collier, J. (1976) Political Leadership and Legal Change in Zinacantan. Law and Society 11(1), pp. 131-163.

Corbridge, S. (2000) Competing Inequalities: the tribal middle-class, tribal politica; identities and the reservation system in the Jharkhand, Bihar, India. Journal of Asian Studies 59(1), pp. 62-85.

Corbridge, S., and Kumar, S. (2002) Community, Corruption, Landscape: tales from the tree trade. Political Geography 21(6), pp. 765-788.

Corbridge, S., Williams, G., Srivastava, M., and Veron, R. (2005) Seeing the State: governance and governmentality in India. (Cambridge: Cambridge University Press).

Das, V. (1992) Jharkhand: castle over the graves. (New Delhi: Inter-India publications). de Sardan, O. (1999) A Moral Economy of Corruption in Africa? The Journal of Modern African Studies 37(1), pp. 25-52.

Devalle, S. (1992) Discourses of Ethnicity: culture and protest in Jharkhand. (New Dehli, California, London: Sage Publications).

Fuller, C., and Harris, J. (2001) For an Anthropology of the Modern Indian State. In Fuller, C. and Benei, V. (eds.): The Everyday State and Society in Modern India. (London: Hurst).

Fuller, C., and Harriss, J. (2001) Introduction: for an anthropology of the modern Indian state. In Fuller, C. and Benei, V. (eds.): The Everyday State: anthropological perspectives on the state and society in modern India. (London: C. Hurst), pp. 1-30.

Gill, S.S. (1998) The Pathology of Corruption. (New Delhi: Harper Collins Publishers India).

Goldman, M. (2001) An Ethnographic Theory of Democracy. politics from the viewpoint of Ilheus's Black Movement Ethnos 66(2), pp. 157-180.

Guha, R. (1999 (1983)) Elementary Aspects of Peasant Insurgency in Colonial India (Durham Duke University Press).

Gupta, A. (1995) Blurred Boundaries: the discourse of corruption, the culture of politics and the imagined state. American Ethnologist 22(2), pp. 375-402.

Gupta, A. (1998) Postcolonial Developments: agriculture in the making of modern India. (Durham, NC: Duke University Press).

Gupta, A. (2005) Narratives of corruption: anthropological and fictional accounts of the Indian State. Ethnography 6(1), pp. 5-34.

Haller, D., and Shore, C., eds. (2005) Corruption: anthropological perspectives. (London: Pluto Press).

Hardiman, D. (1987) The Coming of the Devi: adivasi assertion in Western India. (Delhi: Oxford University Press). 
Harris, O., ed. (1996) Inside and Outside the Law: anthropological studies of authority and ambiguity (London and New York: Routledge).

Hart, K. (2005) Formal Bureaucracy and the Emergent Forms of the Informal Economy: http://www.thememorybank.co.uk/publications/uhpchapter).

Heuze, G. (1996) Workers of Another World: miners, the countryside and the coalfields in Dhanbad (New Delhi: Oxford University Press).

Jeffrey, C., Jeffery, P., and Jeffery, R. (2002) From Textbook to Timepass: education and unemployment in the lives of young men in rural Uttar Pradesh. Paper presented at South Asia Anthropologist Group Meeting.

Kaviraj, S. (1984) On the Crisis of Political Institutions in India. Contributions to Indian Sociology (n.s.) 18(2), pp. 223-243.

Kaviraj, S. (1991) On State, Society and Discourse in India. In Manor, J. (ed.): Rethinking Third World Politics. (Harlow: Longman), pp. 72-99.

Kaviraj, S. (1997) The Modern State in India, pp. 225-250.

Lewis, D., and Mosse, D. (2006) Development Brokers and Translators: the ethnography of aid and agencies. (Bloomfield, CT: Kumarian Press).

Madan, T.N. (1997) Modern Myths, Locked Minds: secularism and fundamentalism in India. (Delhi: Oxford University Press).

Mayer, A. (1981) Public Service and Individual Merit in a Town of Central India. In Mayer, A. (ed.): Public Service and Individual Merit in a Town of Central India. (Oxford Oxford Univesity Press).

Mooij, J. (1992) Private Pockets and Public Policies: rethinking the concept of corruption. In von Benda-Beckmann, F. and van der Velde, M. (eds.): Law as a resource in Agrarian Struggles. ( Wageningse: Wageningse Sociological Studies).

Mosse, D. (2001) Irrigation and Statecraft in Zamindari South India. In Fuller, C. and Benei, V. (eds.): The Everyday State: anthropological perspectives on the state and society in modern India. (London: C. Hurst), pp. 163-194.

Mosse, D. (2005) Cultivating Development: an ethnography of aid policy and practice. (London: Pluto Press).

Nandy, A. (1998) The Politics of Secularism and the Recovery of Religious Tolerance Alternatives 8(pp. 177-194.

Neocleous, M. (1996) Administering Civil Society: towards a theory of state power. (London: Macmillan Press Ltd).

Nuijten, M. (2003) Power, Community and the State: the political anthropology of organisation in Mexico. (London: Pluto Press).

Parry, J. (2000) The 'Crisis of Corruption' and 'The Idea of India' - A Worm's Eye View. In Pardo, I. (ed.): Morals of Legitimacy: between agency and system. (Oxford: Berghan Books), pp. 27-55.

Parry, J., and Bloch, M. (1989) Money and the Morality of Exchange. (Cambridge: Cambridge University Press).

Robertson, A.F. (2006) Misunderstanding Corruption. Anthropology Today 22(2), pp. 8-12.

Roseberry, W. (1988) Political Economy. Annual Review of Anthropology 17(pp. 161-185.

Ruud, A.E. (2001) Talking Dirty About Politics: a view from a Bengali village. In Fuller, C. and Benei, V. (eds.): The Everyday State: anthropological perspectives on the state and society in modern India. (London: C Hurst), pp. 116-137.

Scott, J. (1979) Moral Economy of the Peasant: subsistence and rebellion in Southeast Asia. (Yale: Yale University Press).

Shah, A. (2006) Markets of Protection: the 'terrorist' Maoist movement and the state in Jharkhand, India. Critique of Anthropology 26(3), pp. 297-314. 
Shah, A. (2007) Keeping the State Away: democracy, politics and the state in India's Jharkhand. Journal of the Royal Anthropological Institute 13(1), pp. 129-145.

Singh, K.S. (1966) The Dust Storm and the Hanging Mist (Calcutta.

Taussig, M. (1992) Maleficium: state fetishism In Taussig, M. (ed.): The Nervous System (New York and London: Routledge), pp. 111-140.

Thompson, E.P. (1971) Moral Economy of the English Crowd in the Eighteenth Century. Past \& Present 50(pp. 76-136.

Vishvanathan, S., and Sethi, H. (1998) Foul Play: chronicles of corruption, 1947-1997. (New Delhi: Banyan Books).

Wade, R. (1982) The System of Administrative and Political Corruption: canal irrigation in South India. Journal of Development Studies 18(pp. 287-328.

Wade, R. (1985) The Market for Public Office: why the Indian State is not better at development. World Development 13(pp. 467-497.

Wadley, S. (1994) Struggling with Destiny in Karimpur, 1925-1984. (Berkeley: University of California Press).

WorldBank (1992) Governance and Development. (Washington D.C. .

WorldBank (2007) Strengtening World Bank Group Engagement on Governance and Anticorruption. (Washington DC: World Bank).

\footnotetext{
${ }^{1}$ The focus here is on 'bottom-rung', 'petty' or 'retail' corruption though this should not prevent from considering the arguments here in the context of more major corruption.

${ }^{2}$ Jharkhand is known for one of the oldest autonomy movements in India with the first demands for a separate State within India made in 1928. The struggle for autonomy initially revolved around the idea that the culturally autonomous indigenous people, or adivasis, were exploited and oppressed by the high caste Hindu governments that had ruled them from Bihar and was initially the product of Christian converted adivasis (Devalle, 1992;
}

Singh, 1966). By 1999, one of the peaks of the Jharkhand movement, it had a wider support from educated nonChristian adivasis (mainly urban based). In the Tapu area, however, as I have argued elsewhere (Shah forthcoming), when I arrived to live there in 2000 , only weeks after the state had been formed, most adivasis not only did not know of these significant political changes, but also did not care.

${ }^{3}$ In Jharkhand panchayati elections have not been held since 1978 meaning that the Block Office is responsible for the design and implementation of development plans at the village level.

${ }^{4}$ All names of people and villages are pseudonyms.

${ }^{5}$ The percentages are fixed slightly differently for different schemes.

${ }^{6}$ Corbridge et al estimate that fund leakage from Employment Assurance Schemes in Bihar is between 30-35\% of the total flow of funds (Corbridge et al., 2005:166).

${ }^{7}$ I do not have exact information on the way this dependence works in the Bero Block Office, but Robert Wade's (1982; 1985) model of the corruption-transfer mechanism in Andhra Pradesh provides relevant pointers. 


\footnotetext{
${ }^{8}$ In some of the literature such young men are described as 'unemployed' or 'berozgar' (c.f. Heuze, 1996;

Jeffrey et al., 2002). In Bero, while these men may sometimes classify themselves to outsiders as berozgar, they also see networking as a form of employment.

${ }^{9}$ The transaction is always depicted as one of things but it is often money that transfers hands.

${ }^{10}$ Parry, personal communication. See also Hardiman (1987: 76) and Mosse (2005: 51).

${ }^{11}$ As in Brass's description of police action in Uttar Pradesh, that it is not only a simple case 'of the agents of the state misusing their powers against innocent persons, but a social system in which all are engaged in such actions,' (Brass, 1997:274).

${ }^{12}$ In fact, in many other areas of India, the activities of the modern development state have enabled power structures of the village to change (c.f. Gupta, 1998; Wadley, 1994).
} 